DOI: https://doi.org/10.32782/2305-9389/2020.20.10

УДК $631.6(477.8)$

\title{
Валентина Клюнтер
}

\section{Меліорація на Поліссі (село Секунь)}

Автор розповідає про осушувальну меліорачію - одну із структурних видів гідромеліорації, котру почали проводити на Поліссі у Волинської губернії наприкінці ХІХ століття. Меліорація, щяо передувала Першій світовій війні, носила характер каналізачії боліт і проявлялася в будівниитві каналів: в одних випадках для сплаву лісу, в інших - для розвитку луківниитватна болотах. Споруди на каналах, які використовувалися для сплаву лісу, під час Першої світової та Громадянської воєн булі зруйновани і спалені, неглибока мережа каналів на болотах замулилася $i$ втратила свою осушувальну дію. Осушувальні меліорації в межсах Малого Полісся спричинили трансформацію трунтів у протилежсих напрямах. За умов високої культури осушуваного землеробства вони трансформувалися в осушені окультурені трунти, а за умов низької культури осушуваного землеробства з численними порушеннями рекомендованих агромеліоративних заходів - в осушені деградовані трунти.

Згадано село Секунь $і$ події від часів російського ияарату $i$ до сучасності. Підкреслено, щчо меліорачія давала поштовх економічному життю краю, сприяла запровадженню нових культур $і$ технологій. Вказано, щуо в меліорації земель Полісся тричі спостерігалися ииклічні підйоми й спади. Перші два иикли повязані з зовнішнім факторами світовими війнами, а третій - внутрішній - з переходом на ринкову систему господарювання. Кожен цикл завершувався занепадом осушувальних меліорачій. Таким чином, аналізуючи багаторічну історію вивчення гідроморфних грунтів Волині виділено найважливіші результати. 3 огляду на неоднозначні висновки дощо меліорації на Поліссі сучасних дослідників ї̈ вивчення є надактуальним завданням.

Ключові слова: Волинь, Полісся, Секунь, меліорація, відродження меліорації в умовах дефіциту енергетичних pecypciв.

Valentina Klunter. Land reclamation in Polissya (Sekun village).

The author tells about drainage reclamation - one of the structural types of hydromelioration, which began in Polissya in the Volyn province in the late nineteenth century. Reclamation, which preceded the First World War, was in the nature of the sewerage of swamps and manifested itself in the construction of canals: in some cases for the rafting of forests, in others - for the development of meadow swamps. The structures on the canals used for rafting were destroyed and burned during the First World and Civil Wars, the shallow network of canals in the swamps became silted up and lost its drainage effect. Drainage reclamation within Maly Polissya caused the transformation of soils in opposite directions. Under conditions of high culture of drained agriculture, they were transformed into drained cultivated soils, and under conditions of low culture of drained agriculture with numerous violations of the recommended agro-ameliorative measures - into drained degraded soils. The village of Sekun and events from the time of the Russian tsar to the present are mentioned. It was emphasized that land reclamation gave impetus to the economic life of the region, contributed to the introduction of new cultures and technologies. It is indicated that cyclical ups and downs were observed three times in the reclamation of Polissya lands. The first two cycles are related to external factors world wars, and the third - internal - with the transition to a market economy. Each cycle ended with the decline of drainage reclamation. Thus, analyzing the long history of studying the hydromorphic soils of Volyn, the most important results are highlighted. Given the ambiguous conclusions of land reclamation in Polissya, modern researchers study it is a very important task.

Key words: Volyn, Polissya, Sekun, land reclamation, revival of land reclamation in the conditions of energy resources deficit.

Слово меліорація (melioration) в перекладі 3 латинської на українську мову означає поліпшення. В українському контексті, меліорація - це поліпшення природних умов 3 метою раціонального використання природних ресурсів і органічного ведення сільського господарства. Існує декілька видів меліорації: гідромеліорація, агро-лісо-меліорація, культурно-технічна меліорація, хімічна меліорація, меліорація клімату. Кожна із них має свою структуру. В цьому дописі піде мова про осушувальну меліорацію - одну із структурних видів гідромеліорації, котру почали проводити на території нашого Полісся наприкінці ХІХ століття.

Волинська губернія, як адміністративна одиниця Російської імперії, після відміни кріпосного права, привертала увагу влади до суспільно-політичного і економічного життя краю. Полісся, котре славилося своїми лісами, було таке ж багате і на заболочені ділянки. В цій місцевості селяни в основному займалися тваринництвом. Болота переважали тут луги і для худоби не вистачало випасів. Царська Росія, котра потребувала продуктів харчування для зростаючого населення i сировини для виробництва, не могла свою економіку швидко перевести на «нові рейки». Замість впровадження нових технологій і інтенсифікації виробництва держава пішла відсталим шляхом розширення сільськогосподарських угідь.

Волинська губернія стала однією із перших вотчин царської Росії, де проводились великомасштабні роботи по покращенню природних умов. Початок меліорації на Волині веде свій відлік із 1873 року. Саме тоді в Російській імперії була створена Західна експедиція по осушуванню боліт під керівництвом полковника Генерального Штабу - Йосипа Іполитовича 
Жилінського. Проект, складений цим талановитим інженером-геодезистом, по осушенню заболоченої місцевості Полісся, не мав аналогів у світі.

Роботи проводились вручну, техніки для виконання таких робіт не було. Селяни копали магістральні і бокові канали лопатами. Землю вивозили на підводах. Будувалися плоти, з котрих черпаками чистили русла рік. Мости і дерев'яні шлюзи будувалися за допомогою звичайної сокири. Це була каторжна праця полісян, яка тривала понад двадцять років. На цих роботах гинули люди і коні. Проте в царського уряду не було жалості до робітників, котрі не мали підприємницької жилки і до кінця не могли усвідомити масштаби цієї праці і їі результат.

Наслідком каторжної роботи стали понад 100 тисяч гектарів осушених боліт Полісся. Рідка мережа осушувальних каналів, котрі були вириті для покращення природних сіножатей і полів на територіях маєтків поміщиків дала змогу провести експериментальні засадження полів новими сортами зернових, гречкою, цукровими буряками.

Змінилася і екологічна ситуація в регіоні. Деякі епідемічні захворювання, пов'язані 3 підвищеною вологістю краю і мошкарою, котра їх розповсюджувала, пішли на спад. Проте Йосип Іполитович Жилінський вважав, що виконано лише перший етап робіт, який для тих економічних умов був достатнім. Він наголошував у своїх докладах, що, по мірі зміни умов життя і зростання населення в державі, розпочаті роботи потрібно буде продовжити.

Проте політична ситуація в світі і зокрема в Росії, була напруженою. Після хвилі визвольних воєн і революцій, в Європі різкими темпами розвивалась індустріалізація, котра потребувала нових форм організації виробництва. Фінансова олігархія, в руках якої були зосереджені грошові та матеріальні ресурси монополізувала промисловість і стала відігравати вирішальну роль у політичному житті. У світі складалася нова система відносин, що призвела до формування військово-політичних союзів провідних країн світу для завоювання і захисту світової першості. Назрівала перша світова війна. 3 їі початком майже повністю були припинені меліоративні роботи на Поліссі.

Відновилися вони в нашому краї після того, як частина України опинилася під владою Польщі в 1921 році. В зв'язку з низьким рівнем інженерних систем і їх експлуатацією більшість каналів замулились. I все таки меліоративна система кінця XIX століття, стала основою проведення другої хвилі меліорації на поліських землях.

Передумовою іiі проведення стала політична складова у вирішенні економічного питання Польською державою, відновленою після першої світової війни. Щоб зміцнити своє положення на нових землях і не допустити національно-визвольного руху корінного населення, владою була розроблена програма заселення нових регіонів, «надійним польським елементом», котрий дістав назву «осадники». Польський уряд покладав велику надію на колоністів-осадників, котрі повинні були тримати в покорі місцеве населення, асимілюючи його. 3 другої сторони це була прихована прикордонна охорона. Зрозуміло, що на цю роль підходили найбільш реакційні елементи тодішньої Польщі, в основному це були військові у відставці. Значну кількість осадників складали колишні легіонери контрреволюційного буржуазного режиму націоналіста Пілсудського. Ці переселенці отримували від держави щедрі фінансові субсидії для облаштування на загарбаних землях. Аграрна реформа, започаткована в Польській державі у 1919 році почала набирати нових оборотів згідно з законом від 1925 року. На нових територіях розпочався процес землевпорядкування, котрий передбачав передачу кращих земельних наділів колоністам. Розпочалася масова парцеляція (поділ понаднормових) великих землеволодінь, ліквідація сервітутів (права селян та поміщиків на спільне користування угіддями) та анклавів (внутрішніх ділянок на землі іншого власника), а також комасація (ліквідація земельних невеликих наділів, котрі належали одному власнику з подальшим виділенням такої ж кількості землі в іншому, зазвичай гіршому місці, одним куском). Такі засоби землевпорядкування потребували вкрай невідкладних меліоративних робіт.

Таким чином на Волині розпочалася друга хвиля меліорації. Після детального вивчення окружними та повітовими комісіями ситуацій в повітах, котрі потребували меліоративних робіт, та стану грунтів, було виготовлено карту Волинського воєводства з вказанням вододілів великих і малих річок. Вона послужила основою для технічних проектів нової меліорації земель. 
Так, як Волинське воєводство на той час не мало своїх кваліфікованих спеціалістів у сфері меліорації, у Ковелі, при землемірній школі, було відкрито спеціальні курси, на котрих навчалося приблизно тридцять чоловік.

Інтенсивність проведення меліоративних робіт, під їх керівництвом, припадає десь на 1927 1933 роки. Фінансувалися ці роботи частково державою, частково зацікавленими особами. На населення був накладений податок на проведення меліорації. 3 часом, дивлячись на результати цих робіт, люди самотужки копали канави і копанки за свій рахунок.

Завдяки проведеній меліорації до господарського використання було залучено близько 200 тисяч га землі, із-за чого значно зросла продуктивність сільськогосподарського виробництва краю.

Що саме цікаво, вказані роботи були проведені настільки якісно, що ще й до сьогоднішнього дня окремі канали і споруди справно служать людям.

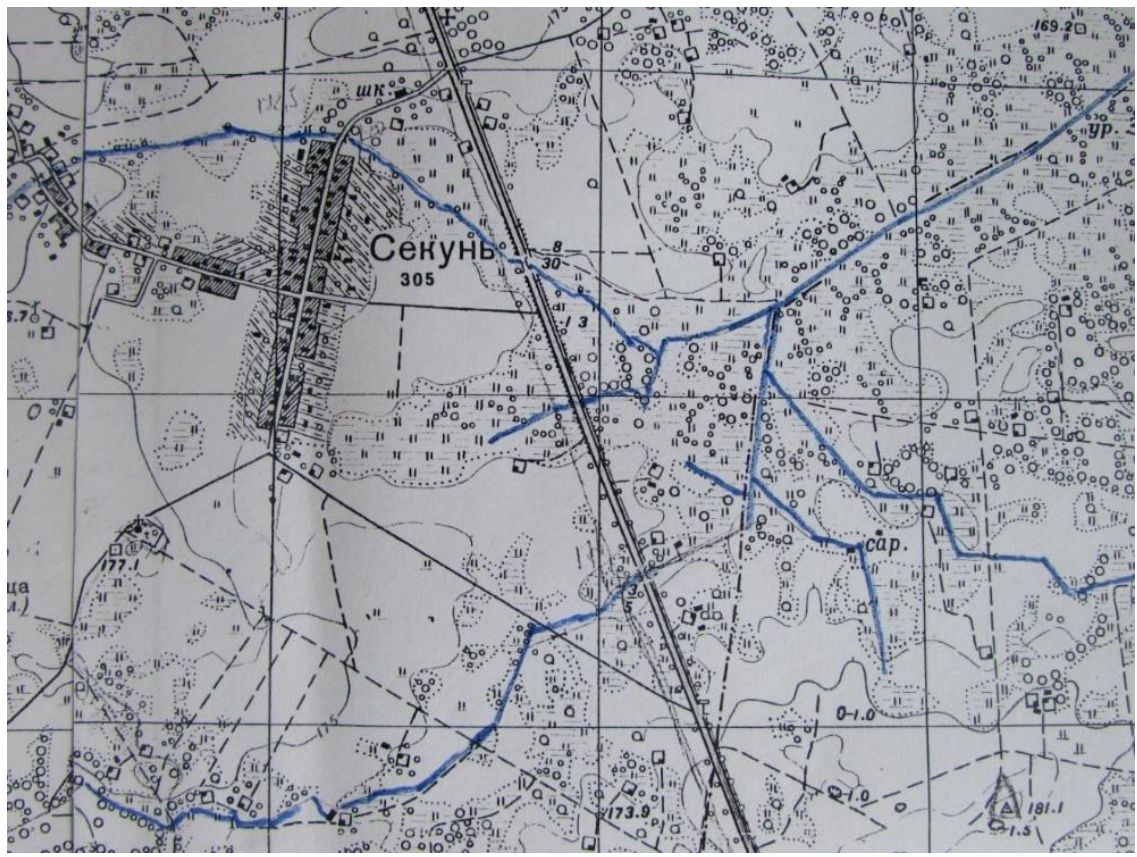

Карта меліоративних каналів, прокладених за Польщі у селі Секунь. Зйомка 1948 року. Головне управління геодезії і картографіï.

Ну ось ми й підійшли до споминів очевидців третьої хвилі меліорації на Волині, зокрема в селі Секунь. Її початок ознаменувався для автора цієї статті, приблизно в 1965 році, великою руйнацією лісів. Село, котре лежало в лісовій колисці, проснулося одного ранку від страшенного гуркоту техніки. Краєвиди на його околицях змінилися буквально за декілька годин. Вільховий ліс, який тягнувся від окраїни Секуня до густих соснових площ Мокреця і Казни, падав замертво під лопатами бульдозерів. Здавалося, що якийсь казковий лиходій заходився трощити дерева в страшенному пориві гніву. Вільшина зі стогоном, обороняючись, 3 трудом піддавалася механізованому монстру. Потім здригаючись від болю кожним листочком, протяжно зойкала i падала під ковшем екскаватора. Всі ці дерева стягувалися у величезні вали навкруги села. Наші шумливі Багна, котрі щорічно, навесні, заселялися тисячами птахів опинилися за цими грізними валами. Великі зграї пташок піднімалися в небо, з шумом кружляючи над зміненою місцевістю. Зайці, котрих раніше ми бачили, лише сполохуючи в лугах чи підлісках, тепер 3 шаленою швидкістю, неначе за ними гнались вовки чи лисиці, проносилися мимо хат і клунь, шукаючи прихистку коло людей. До кінця літа того року, навкруги в гуркоті, гинув для мене навколишній світ. Проте, дощі обмивали вали, на котрих всупереч руйнівній силі, квітували спочатку фіалки, а потім ромашки з дзвіночками. 
Зникла дорога до Великого лісу, зникли поплави і пасовища. Череда розбредалася біля валів, а згодом, коли життєдайна сила трав прикрасила ці мертві гори, наші Чорнушки і Рижухи стали забиратися на них в пошуках корму. Я з болем дивилась на перевернутий світ і ненавиділа всіх тих, хто був причетний до цієї руйнації. Мій дитячий розум і серденько не могли змиритися 3 такою жорстокістю...

Лише через багато років я зрозуміла, що була очевидцем великомасштабної операції під назвою «Меліорація». В наступні роки за описаними подіями за валами працювали цілі бригади людей. Були викопані величезні канави: через Помірки до Казни і далі на Седлище; від неї друга канава брала виток справа перед Казною і тягнулася мимо Багна і села в напрямку хімскладів. 3 володінь Буценського лісу від траси Брест-Ковель тягнулася ще одна водна стрічка, перед Мокрецем, в напрямку Вовчої. Ще одна велика канава брала початок в Малиннику і повільно несла води через Рудавку, далі мимо Дячишиної і Їгорцьової хатів проходила через Широку в напрямку шосе. Наступна водна стрічка брала початок перед Горицями, навпроти Циганської нивки, і оминаючи кладовище і село текла також до автомагістралі.

Корчуванням лісів займалася Ковельска ЛМС (луго-меліоративна станція), а прокладанням дренажу і будуванням містків - Волинське БМУ-62, пізніше переіменоване в Ковельську ПМК-62. В ній працювали і вихідці з Секуня: автокранівники Григорій Микилюк, Григорій Данилюк, а також Андрощук Василь Нікандрович - нач. виробничо-технічного відділу.

На цих роботах були задіяні бульдозери, екскаватори, канавокопачі, грейдери. Найвагомішою технічною одиницею був трактор Т-130, котрий являвся базою для навісного обладнання. Та все ж рушійною силою в цьому процесі були люди, котрі невтомно трудилися над зміною природних умов рідного краю. Люди вірили і надіялися, що ці зміни зроблять їхній край житницею.

Ще багато років після описаних подій жителі Секуня самотужки розчищали вали від повалених дерев і пнів, витрушуючи і розрівнюючи сотні тонн грунту. Неначе рана на тілі повільно заживала земля. Засяяли лісами далекі овиди. На жаль, зникло багато рідкісних представників флори і фауни.

На початку 80-х років минулого століття в околицях Секуня були прокопані ще три водомагістралі. Перша із них, величезна канава, тягнеться обіч автотраси Брест-Ковель. Друга бере початок від урочища Гориці і поза Кривухою і Пацихою тягнеться полями до шосе, 3'єднуючись 3 першою. Цей об'єкт, збудований Голобською ПМК, дістав назву поперечного каналу. I третя водомагістраль, збудована Ковельською ПМК, канал, що тягнеться з глибини лісу за Гандригорами в напрямку хутірця Данилюків. Оминаючи данилюківські володіння канал впадає на Широкій в іншу меліоративну магістраль.

Чи була раціональною така великомасштабна меліорація в нашому краї? Напевно, ні! Природа потихеньку відвойовує своє право володіти ландшафтами. Хоча втручання людини зробило незворотним процес відновлення боліт на Поліссі, котрі грали величезну роль в природньому коловороті. Багато масивів змінило своє природнє обличчя, не принісши користі...

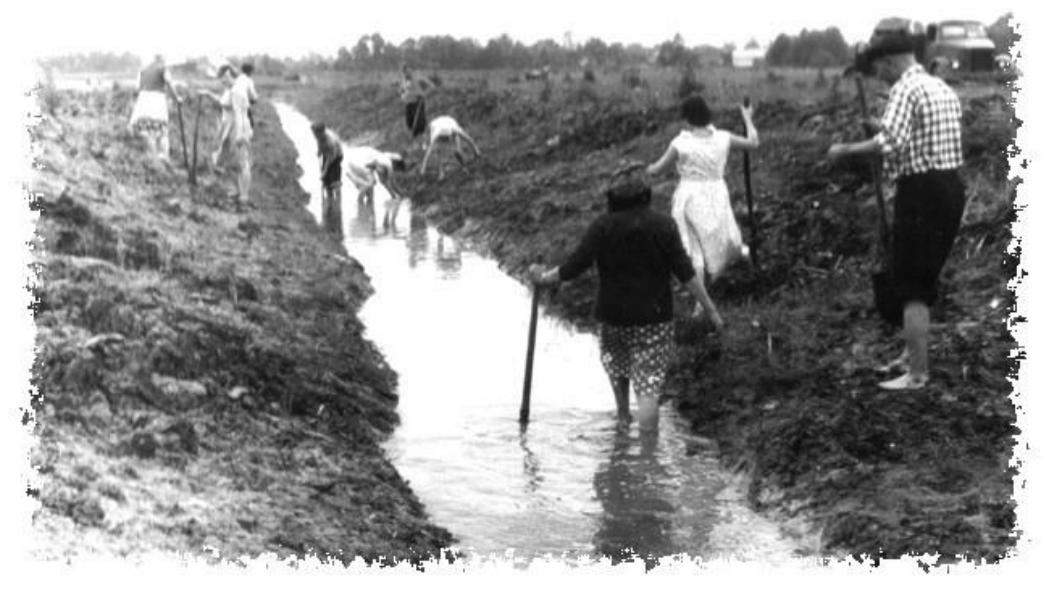

Фото з Інтернету: Так розпочиналась меліорація на Волині.

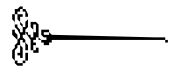




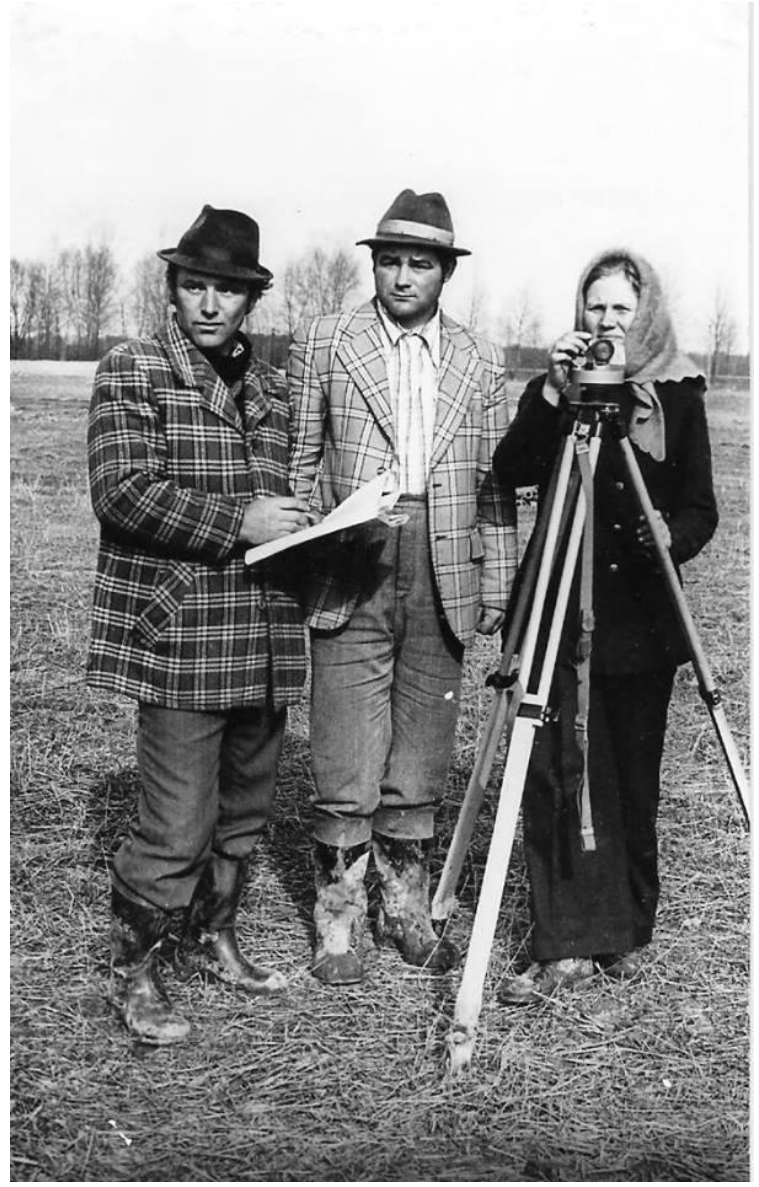

На об’єкті в Секуні: працівники Ковелської ПМК -62 майстер Грабовий Петро , нівелювальники Омельчук Микола і Миронюк Марія . Фото Іллі Зінчука (з Інтернету).
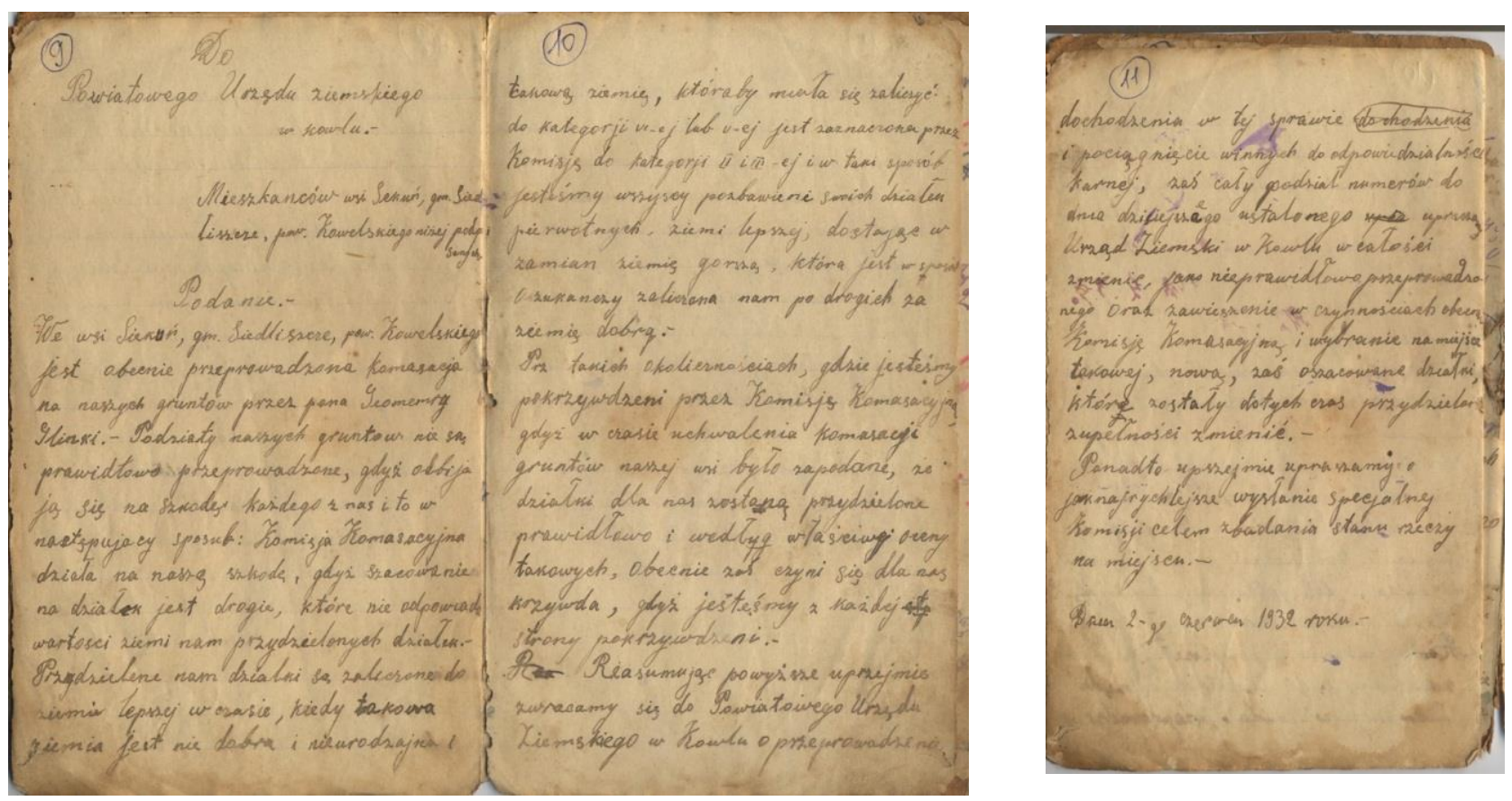


\section{ДО ПОВІТОВОГО ЗЕМСЬКОГО УЇЗДУ В КОВЕЛІ}

(Переклад згідно з оригіналом)

До повітового Земського Уїзду в Ковелі

Землеустрій (kamasaja) жителів села Секунь, гміна Седліще, повіту Ковельського.

(Підписи)

Подання

В селі Секунь, гміни Седліще, повіту Ковельського зараз проведена комасація (землеустрій) на наших землях паном Геометри Глінскі. Поділи наших грунтів проведені несправедливо, тому це наносить шкоду кожному з нас. Таким чином, Комісія по Землеустрою діє нам на збиток, тому що оцінювання земельних участків $\epsilon$ дороге і не відповідає вартості приділених нам участків.

Приділені нам участки є залічені до землі кращої, тоді коли ось ця земля не $є$ добра, неврожайна і $є$ такою землею, яка мала би залічитись до категорії VI-ої або V-ої, а $є$ залічена Комісією до категорій II і III-їй, і в такий спосіб ми усі є позбавлені своїх первинних наділів землі кращої, діставши замість неї землю гіршу, яка нам обманним чином залічена по дорогому за землю добру.

При таких обставинах, ми є скривджені Комісією Комасаційною (перевірочною), тому що в час ухвалення комасації грунтів нашого села було зазначено, що наділи для нас будуть приділені справедливо і відповідно до властивої оцінки таких. Зараз же для нас відбувається кривда, тому що ми є скривджені з кожної сторони.

Підсумовуючи вищесказане, уклінно звертаємось до Повітового Уїзду Земського в Ковлі про проведення в цій справі і притягнення винуватців до карної відповідальності, щоб весь розподіл номерів, встановлений Земською Управою в Ковлі, як неправильно проведений і завісити в чинності Комісію Комасаційну і вибрати на їі місце нову, щоб змінити оцінення наділів, які були приділені.

Крім того уклінно просимо про те, щоб вислали якомога швидше Комісію з метою перевірки стану речей на місці.

Дня 2-го червня 1932 року.

Ці документи взяті з господарчого зошита жителя села Секунь Ткачука Данила Денисовича. 